\title{
Society Education Media About Islamic Law Through Web-based Application
}

\author{
Siah Khosyi'ah* \\ Magister of Islamic Economics, Postgraduate Program \\ UIN Sunan Gunung Djati \\ Bandung, Indonesia \\ *siah.khosyiah@uinsgd.ac.id \\ Barzan Faizin \\ Islamic Broadcasting Communication \\ UIN Sunan Gunung Djati \\ Bandung, Indonesia \\ barzanfaizin@uinsgd.ac.id
}

\author{
Dian Sa’adillah Maylawati \\ Department of Informatics \\ UIN Sunan Gunung Djati \\ Bandung, Indonesia \\ diansm@uinsgd.ac.id
}

\author{
Muhammad Ali Ramdhani \\ Department of Informatics \\ UIN Sunan Gunung Djati \\ Bandung, Indonesia \\ m_ali_ramdhani@uinsgd.ac.id
}

\begin{abstract}
The majority of Indonesia's population are Muslims who cannot separate the rules of the Islamic religion in the practice of daily life. Therefore, it is important for Muslims to know the rules in Islamic law. This study aims to build a websitebased application that can be a media of education for the society that is practical, effective, and efficient, which can be accessed anywhere and anytime, which related to Islamic law. This study uses Scrum Software Development Methodology which is one of the Agile methods. For software analysis and design modeling, this study use object oriented approach with Unified Modeling Language. The application that built has 37 product backlogs with 4 main function, among others function for discussion forum, personal chat with expert, video, and e-book. This study succeeded in producing a prototype and its implementation in the form of a web-based application with all the functions that have been tested with the black-box testing approach. The result of black-box testing shows that 37 product backlogs or functional requirements of the application already corrected. This study contributes to providing information, communication and consultation media for public education related to Islamic law
\end{abstract}

Keywords-agile, Islamic law, society education, software engineering, scrum, unified modeling language, web-based application

\section{INTRODUCTION}

In the Industrial 4.0 era, all human activities cannot be separated from the use of technology, especially the internet. Not less than 3.9 billion people in the world are recorded connected to the internet [1,2], even in Indonesia until April 2019 there were 171.17 million Internet users in Indonesia or $64.8 \%$ of the 264 million population [3]. This fact shows that internet users have experienced a fairly fast increase of around $8.8 \%$ since January 2019 , which reached $56 \%$ of internet users in Indonesia [4]. Of course, this phenomenon cannot be separated from the rapid and rapid development of technology. This of course needs to be put to good use. The application of technology can be carried out in various sectors and human activities, including in the field of religious studies.

Islam is one of the largest religions in the world, reaching 1.6 billion of the world's population of about 7.5 billion [5]. Indonesia is the country with the largest Muslim population in the world, reaching 222 million people [6]. Various problems in studying, understanding, and implementing Islamic law as rules and guidelines for Muslims in carrying out their daily activities often arise in various groups and ages. Islamic law is the rules, norms, rules from Allah SWT which are contained in the Qur'an and Hadith as the basis and guidance for living life for Muslims, which are closely related to shari'ah and fiqih. [79]. Sharia is fundamental and absolute which shows unity in Islam such as aqidah (faith) and akhlaq (morality) [9-11]. Meanwhile, fiqh (Islamic jurisprudence) is instrumental in nature, having a relationship with syara laws' which are limited in scope to regulate human actions, are relative and dynamic so that they show diversity in Islam. $[9,10,12]$. In the scope of Islamic jurisprudence, Islamic law includes muamalah (which deals with social interactions) and worship.

In this study, solutions to all problems both sharia and fiqh in Islamic law are packaged in an information system that utilizes internet technology so that it can be accessed online, anytime, anywhere, and is flexible / dynamic following the latest problems faced. Of course, many related research and information system products have been produced. Information system technology has begun to be associated with Islamic studies, such as expert systems to solve inheritance problems $[13,14]$, information systems and decision support systems to 
solve problems related to zakat [15-17], geographic information system to determine the distribution of qurban animals [18], and other information systems associated with Islamic studies. However, from the many researches on information systems related to issues of Islamic law, there are not many studies that combine technological science in building software or information systems with Islamic legal studies as its object. This research does not only produce software products, but also applies software development methods as a whole to produce quality software. The system built also involves stakeholders from various circles, including a team of developers and managers who have expertise in the field of information technology, Islamic law experts who fill in content as well as consultants, and of course all levels of society who need information and consultation related to Islamic law. Currently there are several websites that provide information related to Islamic law, such as dakwah.id [19], Muslimat Nahdatul Ulama Online (MNU Online) [20], as well as the personal website of an expert or boarding school institution [21,22]. However, it turns out that from all the online media, the consultation provided is only one-way in the form of the materials presented, it has not involved Islamic law experts interactively connected with people who need consultation. In addition, the material discussed is still focused on the study of certain Islamic laws, such as inheritance or worship only. This research is expected to produce a "house" that accommodates people who need information and solutions related to Islamic law, experts who share their knowledge, and as a medium for direct interaction between the community and experts.

Several researches on information systems and information technology related to Islamic law include: (1) "Analysis of Rules for Islamic Inheritance Law in Indonesia Using Hybrid Rule Based Learning" [23], who built an expert system for inheritance distribution issues based on Islamic law by combining rule-based learning methods, namely the Forward Chaining and Davis-Putman-Logemann-Loveland (DPLL) algorithms. Where, all rules for the distribution of inheritance have been completely defined and there are rules for the distribution of inheritance that have developed because they have adapted to the customs, culture and habits of the Indonesian people; (2) "Designing Expert System for the Distribution of Inheritance according to Islamic Law (Fara'id)" which also built the software to calculate the distribution of inheritance based on Islamic law by defining all conditions in the program code. [14]; (3) "Regional Geographical Information Systems Eligible to Receive Qurban Meat in the City of Padang" [18], which utilize geographic information system technology to spread qurban animals so that they are evenly distributed and reach the rightful people, based on area, place, route, distance traveled, number of citizens, number of Qurban animals; (4) "Development of Management Information Systems for Zakat, Infaq, Shadaqah, Waqf and Grants Using the Waterfall Method" [15], which builds an information system for managing zakat, infaq, shadaqah, waqf, and grants so that their distribution is right on target; (5) "Designing a Web-Based Zakat Information System" [17] which built a web-based zakat management information system, where the system displays information about charity, calculating zakat services, online zakat payment services with payment confirmation which is useful for making it easier for people who already have assets that can be obtained by zakat, and with this website, it enables the finance department in the process of managing zakat; (6) "Decision Support System for Determination of Mustahik (Zakat Recipients) Using the Fuzzy AHP (F-AHP) Method" [16], which builds a decision support system in order to determine whether someone is worthy of receiving zakat, where this study utilizes one of the machine learning methods, namely Fuzzy logic combined with AHP (Analytical Hirarcy Process); (7) "Product Information System and Data for Hajj and Umrah Pilgrims Candidates at PT. Travellindo Lusiyana Banjarmasin Web-Based "which builds an information system to manage goods needed for Hajj and Umrah pilgrims [24]; (8) "Hajj and Umrah Ritual Learning Application Based on Android" [25] which uses mobile technology as a learning medium for Hajj and Umrah rituals; and (9) "Building a Hajj Travel Bureau Decision Support System" [26] which builds a decision support system to select or select trusted haj and umrah travel service bureaus so as to avoid unprofessional service bureaus that can cause harm to prospective pilgrims in the future, such as fraud, illegal pilgrims and facilities and infrastructure. which is not feasible during the Hajj and Umrah pilgrimages.

From several related studies, information system technology has been widely used to solve problems related to Islamic law, such as distribution of inheritance, zakat, haj management, and so on. However, there is no information system that combines all studies of Islamic law in one medium by involving Islamic law experts and the public more actively. This research is expected to be able to become a forum and media for public education that provides various information related to Islamic law, and bridges people to have direct and active consultation with experts to get solutions to the problems related to Islamic law they face.

\section{MEthodOLOGY}

The methodology applied in this research includes: literature study and collection of research instruments. This research begins by conducting a study of the literature related to Islamic law, Scrum Methodology, object-oriented software modeling, Unified Modeling Language, and previous related studies. Next is the stage of collecting the instruments needed during the research, especially on the hardware and software requirements to build the system. The framework for this research is shown in Figure 1, which starts from collecting facts and phenomena, seeing opportunities, determining the approach taken, implementing it to producing research output. 


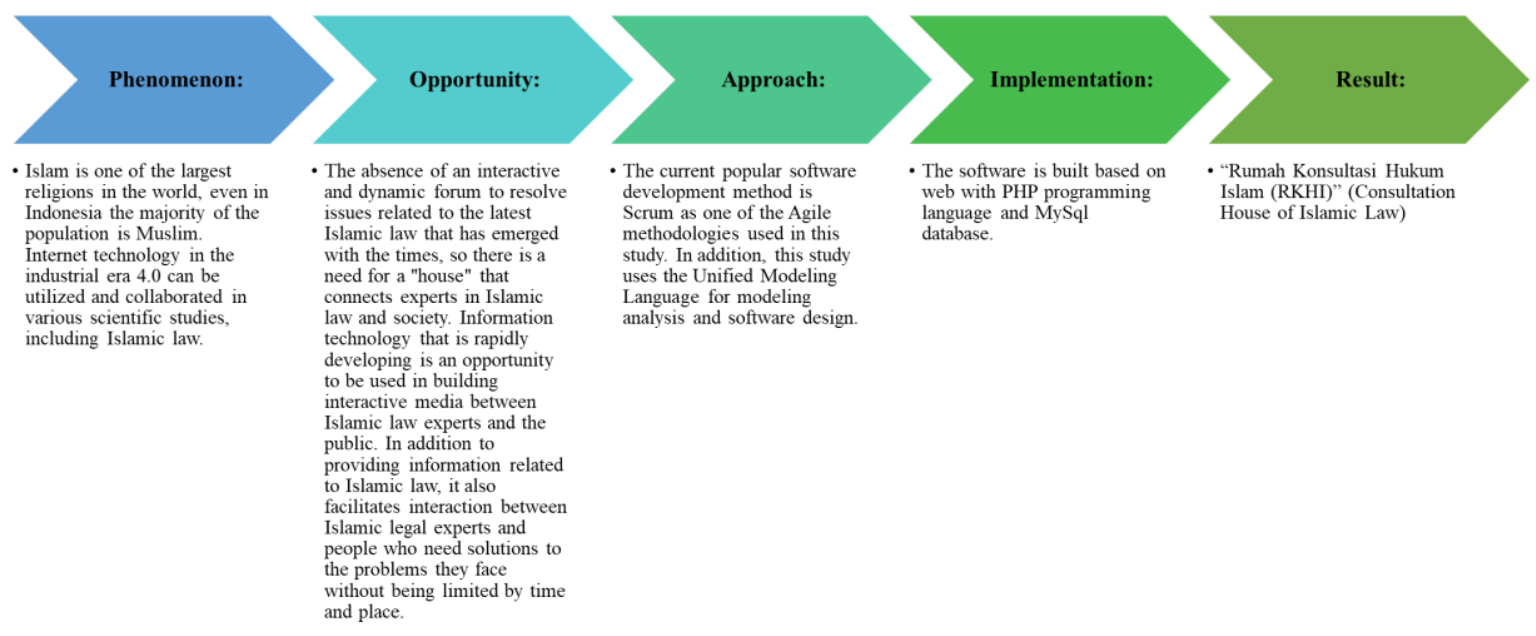

Fig. 1. Research framework.

The software development methodology has developed quite significantly. The formerly rigid method in which each step had to be followed in sequence, is like the Waterfall method [27,28], nowadays it is more dynamic and flexible depending on user needs, so that it is oriented towards product and user satisfaction. However, still pay attention to the systematics of software development in order to maintain quality, not only the software product produced, but also the quality of the software process and documentation. The currently popular software development method is the Agile methodology [29-31], oriented to product and user satisfaction with a relatively fast process. Of the many Agile methods such as Crystal Clear, Extreme Programming, Feature Driven Development, Dynamic Systems Development Method (DSDM), and others, the Scrum method is the most widely used Agile method [32,33]. The Scrum method is an Agile method that is easy to understand and implement [34], but requires discipline in every process. Therefore, this study uses the Scrum methodology as a software development method.

In accordance with the stages in the Scrum method, this study has a scheme depicted in Figure 2 based on the Scrum stages, including creating or defining a product backlog, determining each Sprint Goal, conducting a Kickoff Meeting, conducting a Sprint, conducting Final Revision, and finally the Review stage. Retrospective, Release Acceptance Product and Closing. Where, in every Sprint there will be a Sprint Planning Meeting, Dialy Scrum, Developing Sprint Backlog (Analysis, Design, Coding, and Integrated Testing), as well as Review, Retrospective, Release Product Backlog.

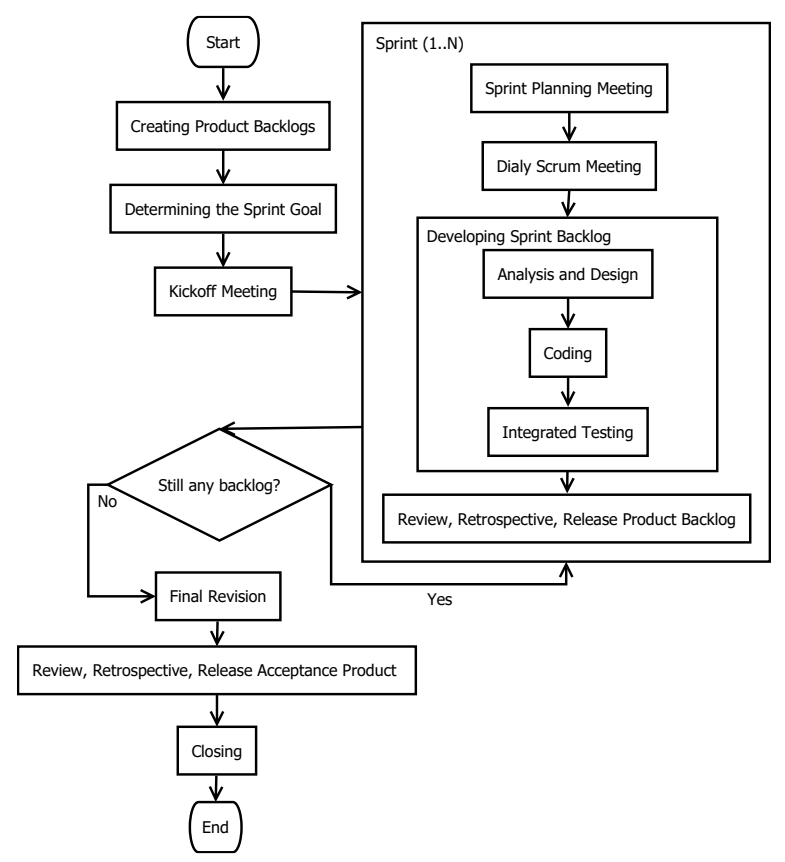

Fig. 2. Implementation of scrum methodology.

\section{RESULTS AND DISCUSSION}

\section{A. Islamic Law}

Islamic law is the rules that originate in the Al-Qur'an as the word of Allah SWT [8], which is the control of all Muslim activities. Islam itself comprehensively consists of aqidah, syari'ah (sharia), and akhlaq (morals) (shown in Figure 3). Where aqidah is a belief or belief that is strong, firm, binding, where Muslims believe in Allah as God and Muhammad is the messenger of Allah. Shari'ah means the rules or laws of Allah that must be followed in all activities of a Muslim's life, which includes aqidah, worship, morals, and muamalah. Meanwhile, morals are behavior, character, habit, behavior, character that is attached to a person to do a good deed in accordance with Islamic law. 


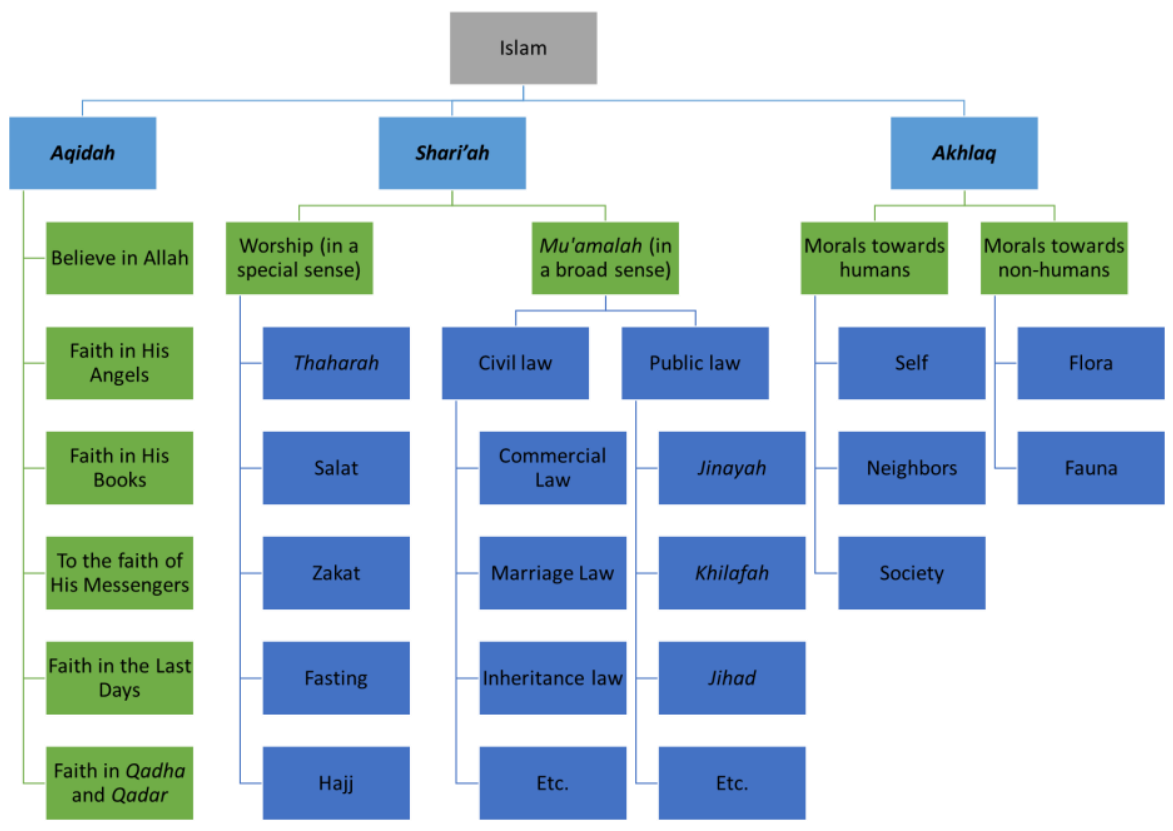

Fig. 3. Comprehensive Islamic scheme.

Basically, the principles of Islamic law are syari'ah, fiqih, and qanun [8]. In contrast to sharia, jurisprudence is practical, which derives from and relates to sharia laws, either resulting from ijtihad (agreement of the scholars) or without ijtihad. There are clear differences between sharia and fiqih, among others [8,9]: (1) The provisions of the Shari'a are contained in the Qur'an and the hadith books. What is meant by sharia is the revelation of Allah and the sunnah of the Prophet Muhammad as His Messenger. Meanwhile, figh is a human understanding that fulfills the requirements of sharia and is contained in fiqh books; (2) Sharia is fundamental and has a broader scope, including morals and creed. Meanwhile, fiqh is only instrumental in nature, it is limited to laws governing human actions, which are commonly referred to as legal actions; (3) Sharia is the stipulation of Allah and the provisions of His Messenger so that it is eternal. While fiqh because it is a human work, it is very possible to experience changes according to the times and times; (4) There is only one Sharia, while there are many fiqh because it is a human understanding. As there are several different schools of jurisprudence fâqih or fuqahâ', it is known as madzhab or madzâhib; (5) Sharia shows the concept of unity in Islam, while figh shows the diversity of thoughts that are encouraged in Islam.

Furthermore, qanuns are laws, rules that are comprehensive in nature which are human products for certain cases or fields that regulate the way of life and relationships among humans, both individually, society and the state.

Both comprehensively and in scope in the sense of fiqh, Islamic law is divided into worship and muamalah. The time of worship covers the relationship between humans and their God, among others, thaharah, prayer, fasting, zakat and hajj. Whereas muamalah in a broad sense is related to the relationship between humans and each other, which is divided into two parts, namely civil law and public law $[34,35]$. Civil law, among others: Munâkahât, regulates everything related to marriage and divorce and all legal consequences; Wirâtsat, regulates all matters with the heir, heirs, inheritance, and the distribution of inheritance. This Islamic heritage law is also known as farâidh law; and Mu'âmalah in a special sense, regulating material issues and rights over property, human relations arrangements in matters of buying and selling, leasing, borrowing and lending, unions, contracts, and so on Meanwhile, Islamic public law includes: Jinâyah, which contains rules regarding actions that are punishable by punishment, both in the hudûd jarîmah (serious punishment) and in the jarimah ta'zîr (light punishment). What is meant by jarîmah is a criminal act. Jarîmah hudûd is a criminal act whose form and legal limits have been determined in the Qur'an and as-Sunnah (hudûd plural hadd, meaning limit). Jarîmah ta'zî̀ is a criminal act whose form and threat of law is determined by the authorities as a lesson for the perpetrator (ta'zîr means teaching or lesson); Al-Ahkam asShulthanniyyah, discussing issues related to the head of state / government, the rights of central and regional governments, regarding taxes, and so on; Siyâr, regulates matters of war and peace, manages relations with adherents of other religions and other countries; and Mukhâsamat which regulates judicial, judicial and procedural matters.

\section{B. Information System}

Information systems are a combination of business processes, work procedures, information, people and technology that facilitate activities in order to achieve organizational goals [36-38]. The word "system" means "a collection of components that have an element of interrelation with one another". The information system is a collection of components within a company or organization that are related to the process of creating and flowing information [39]. In this case, information technology is only one small component in the corporate format. Other components are: processes and procedures, organizational structure, human resources, 
products, customers, suppliers, partners, and so on as illustrated in Figure 4.

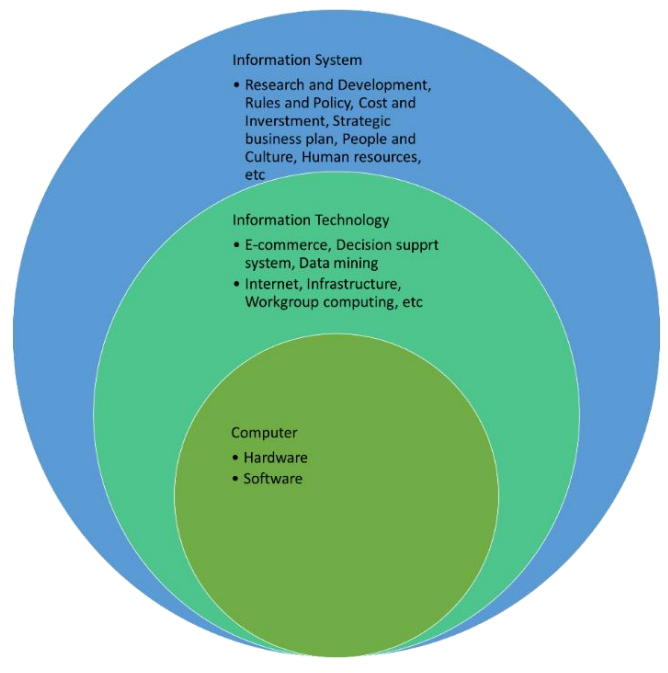

Fig. 4. Information systems, information technology, and computers.

In general, information systems projects within a company or organization can be categorized into three broad groups. The first group is a project that is the development of an information technology infrastructure network, involving matters ranging from the procurement and installation of standalone computers, to planning and developing LAN (Local Area Network) and WAN (Wide Area Network) network infrastructure. The second group is the implementation of application program packages purchased in the market and implemented in companies, ranging from small software such as Microsoft retail products to integrated ERP-based applications, such as SAP and BAAN. The final group is the planning and development of specially made applications (customized software), both by internal companies and by working with external parties such as consultants and software houses. Apart from the different characteristics behind the three types of projects, in general there are six stages (shown in Figure 5) which are usually used as stepping stones or methodologies in carrying out these development activities, including the planning, analysis, design, construction, implementation, and maintenance.
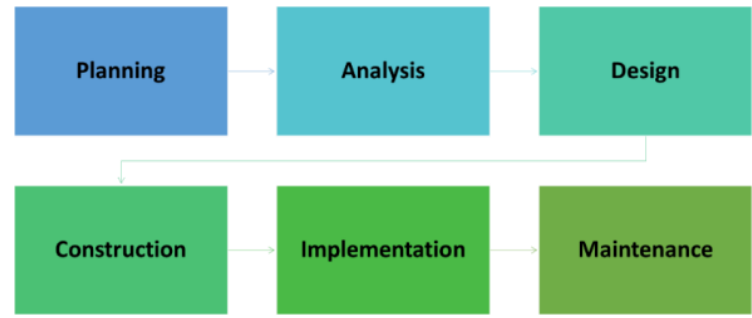

Fig. 5. Main stages of information systems.

\section{Scrum Methodology Implementation}

1) Creating product backlog: Product backlog is a term in the Scrum method for the functional requirements of the system to be built. In this study, the defined product backlog is shown in Table 1. While the system interface requirements are divided into user interfaces, software interfaces, hardware interfaces, and communication interfaces.

TABLE I. PRoduct BACKLOG Sistem "Rumah KonSUltasi HuKum ISLAM (RKHI)" - CONSULTATION HOUSE OF ISLAMIC LAW

\begin{tabular}{|c|c|}
\hline ID & Description \\
\hline PB-RKHI-001 & The RKHI system can provide a registration form \\
\hline PB-RKHI-002 & The RKHI system can verify expert data \\
\hline PB-RKHI-003 & The RKHI system can edit profiles \\
\hline PB-RKHI-004 & The RKHI system can view other people's profiles \\
\hline PB-RKHI-005 & $\begin{array}{l}\text { The RKHI system can provide a discussion forum } \\
\text { management feature }\end{array}$ \\
\hline PB-RKHI-006 & $\begin{array}{l}\text { The RKHI system can provide a discussion forum } \\
\text { topic management feature }\end{array}$ \\
\hline PB-RKHI-007 & $\begin{array}{l}\text { The RKHI system can provide a feature to manage } \\
\text { topic comments }\end{array}$ \\
\hline PB-RKHI-008 & The RKHI system can search for discussion forums \\
\hline PB-RKHI-009 & $\begin{array}{l}\text { The RKHI system can search for discussion forum } \\
\text { topics }\end{array}$ \\
\hline PB-RKHI-010 & $\begin{array}{l}\text { The RKHI system can receive input selected by } \\
\text { experts who want to send messages }\end{array}$ \\
\hline PB-RKHI-011 & The RKHI system can display private chat frames \\
\hline PB-RKHI-012 & $\begin{array}{l}\text { The RKHI system can minimize private chat frames } \\
\text { when there is a button minimize input }\end{array}$ \\
\hline PB-RKHI-013 & $\begin{array}{l}\text { The RKHI system can provide a feature to close } \\
\text { chat frames }\end{array}$ \\
\hline PB-RKHI-014 & $\begin{array}{l}\text { The RKHI system can receive message and file } \\
\text { input }\end{array}$ \\
\hline PB-RKHI-015 & The RKHI system can display messages and files \\
\hline PB-RKHI-016 & The RKHI system can display unread messages \\
\hline PB-RKHI-017 & $\begin{array}{l}\text { The RKHI system can display notification of new } \\
\text { messages }\end{array}$ \\
\hline PB-RKHI-018 & The RKHI system can accept guest name input \\
\hline PB-RKHI-019 & The RKHI system can accept message input \\
\hline PB-RKHI-020 & $\begin{array}{l}\text { The RKHI system can display messages with } \\
\text { photos, names, and color blocks in the chat itself }\end{array}$ \\
\hline PB-RKHI-021 & The RKHI system can receive designation messages \\
\hline PB-RKHI-022 & $\begin{array}{l}\text { The RKHI system can display the mention message } \\
\text { with a color block of the person being mentioned }\end{array}$ \\
\hline PB-RKHI-023 & $\begin{array}{l}\text { The RKHI system can reject guest names that have } \\
\text { joined the open chat }\end{array}$ \\
\hline PB-RKHI-024 & The RKHI system can upload Source \\
\hline PB-RKHI-025 & $\begin{array}{l}\text { The RKHI system can provide a Source delete } \\
\text { feature }\end{array}$ \\
\hline PB-RKHI-026 & $\begin{array}{l}\text { The RKHI system can display random source } \\
\text { recommendations }\end{array}$ \\
\hline PB-RKHI-027 & $\begin{array}{l}\text { The RKHI system can provide a source search } \\
\text { feature }\end{array}$ \\
\hline PB-RKHI-028 & The RKHI system can display source search results \\
\hline PB-RKHI-029 & $\begin{array}{l}\text { The RKHI system can display the source selected } \\
\text { by the user }\end{array}$ \\
\hline PB-RKHI-030 & The RKHI system can download book sources \\
\hline PB-RKHI-031 & The RKHI system can upload Videos \\
\hline PB-RKHI-032 & RKHI system can provide Video delete feature \\
\hline PB-RKHI-033 & $\begin{array}{lllll}\text { The RKHI system can display video } \\
\text { recommendations }\end{array}$ \\
\hline PB-RKHI-034 & $\begin{array}{l}\text { The RKHI system can provide a video search } \\
\text { feature }\end{array}$ \\
\hline PB-RKHI-035 & The RKHI system can display video search results \\
\hline PB-RKHI-036 & $\begin{array}{l}\text { The RKHI system can display videos selected by } \\
\text { the user }\end{array}$ \\
\hline PB-RKHI-037 & The RKHI system can download videos \\
\hline
\end{tabular}


2) User interface: The interfaces needed to operate this software are divided into 3 types of user groups, namely clients, experts, and admins. The user interface that will be displayed for the client group is as follows: (1) Discussion forum topic selection screen. Contains choices of discussion forum topic titles; (2) Send private message screen. On this screen, there will be a client's private chat room with an expert; (3) Video selection screen. On this interface, there is a selection of videos about existing Islamic law; (4) Book selection screen. On this interface, there is a selection of sources about existing Islamic law; (5) As for the expert group, there are several types of display screens that access the system, namely: (a) Discussion forum topic selection screen. Contains choices of discussion forum topic titles, where experts can create new forums; and (b) Send private message screen. On this screen the expert can reply to client personal question; (6) Video selection screen. On this interface, there is a selection of videos about existing Islamic law. And there is a video upload button; and (7) Book selection screen. On this interface, there is a choice of sources about existing Islamic law, and there is a book upload button.

a) Interface software: The software supported by this system is the Linux operating system and uses the MySQL DBMS.

b) Hardware interface: In the Islamic Law Consultative House (RKHI) system there is no hardware connected directly to the system.

c) Communication interface: The communication interface needed to support this system is the use of a network connected to the internet. The security system used to protect information on this system is to provide a password for certain accesses. In addition, HTTPS protocol is used to connect to the bank's network.

3) Determining the sprint goal: The RKHI system provides forum services that can be accessed by experts and users who already have an account. The forum provides content to create new discussion titles and discussion pages. In addition, the RKHI System application provides Openchat which can be accessed by experts, users who have registered and those who have not registered. For users who have not registered, they must first enter the guest name. In addition, users who have registered can send messages individually to get more details from the intended experts. The RKHI system also provides video and book content that can be accessed and downloaded by registered experts and users. The RKHI System also has a special profile page for experts and users.

4) Kickoff meeting: Kick-off Meeting is an activity to prepare and ensure that all product backlogs and sprint goals are well defined and complete, so they are ready to enter the sprint stage.

5) Sprint: Sprints carried out at this stage are generally divided into 6 appropriate sprints, including Sprint for the
Video feature, Sprint for the Resource Book feature, Sprint for the Expert and Client profile feature, Sprint for the Personal Consultation feature (Private Chat and Email), Sprint for Open Chat, and Sprint for the General Discussion or Forum feature. At the software development stage, each sprint produces a module in accordance with the software design that has been designed. The design uses an object-oriented Unified Modeling Language (UML) model [40,41], and is suitable for the Scrum methodology which is also object-based and prioritizes the modularity of each function and module. UML diagrams used include Use Case Diagrams, Class Diagrams, Sequence Diagrams, Activity Diagrams, Component Diagrams, and State Diagrams. Figure 6 and 7 shows the Use Case Diagram and Class Diagram in the construction of this RKHI. Meanwhile, Figure 8 is an example of a user interface design for this RKHI.

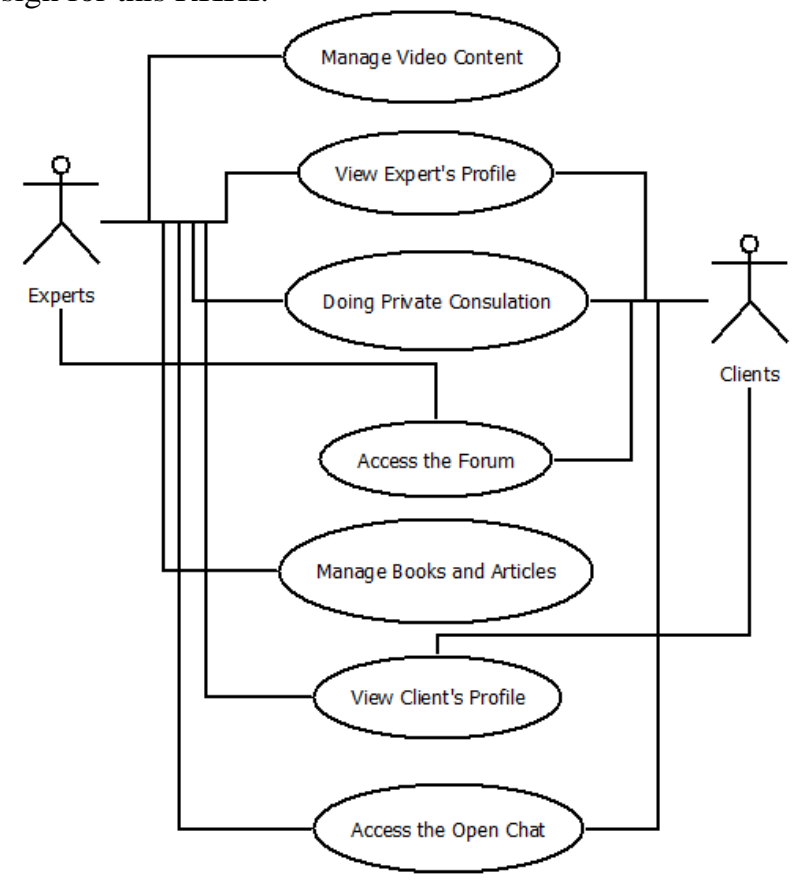

Fig. 6. Use case diagram of RKHI 

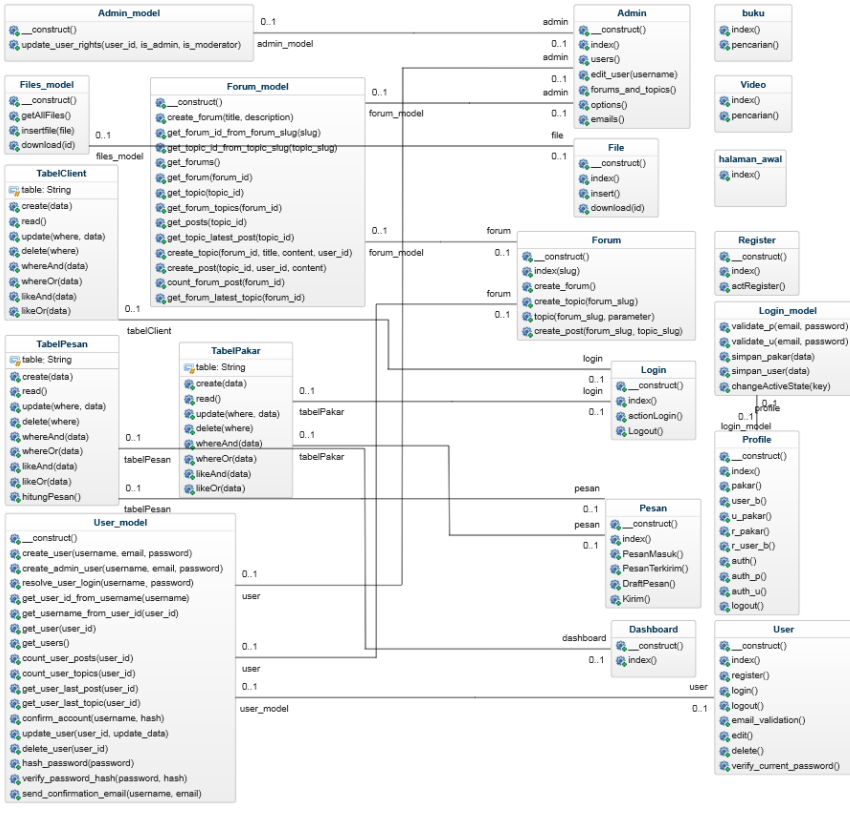

Fig. 7. Class diagram of RKHI.

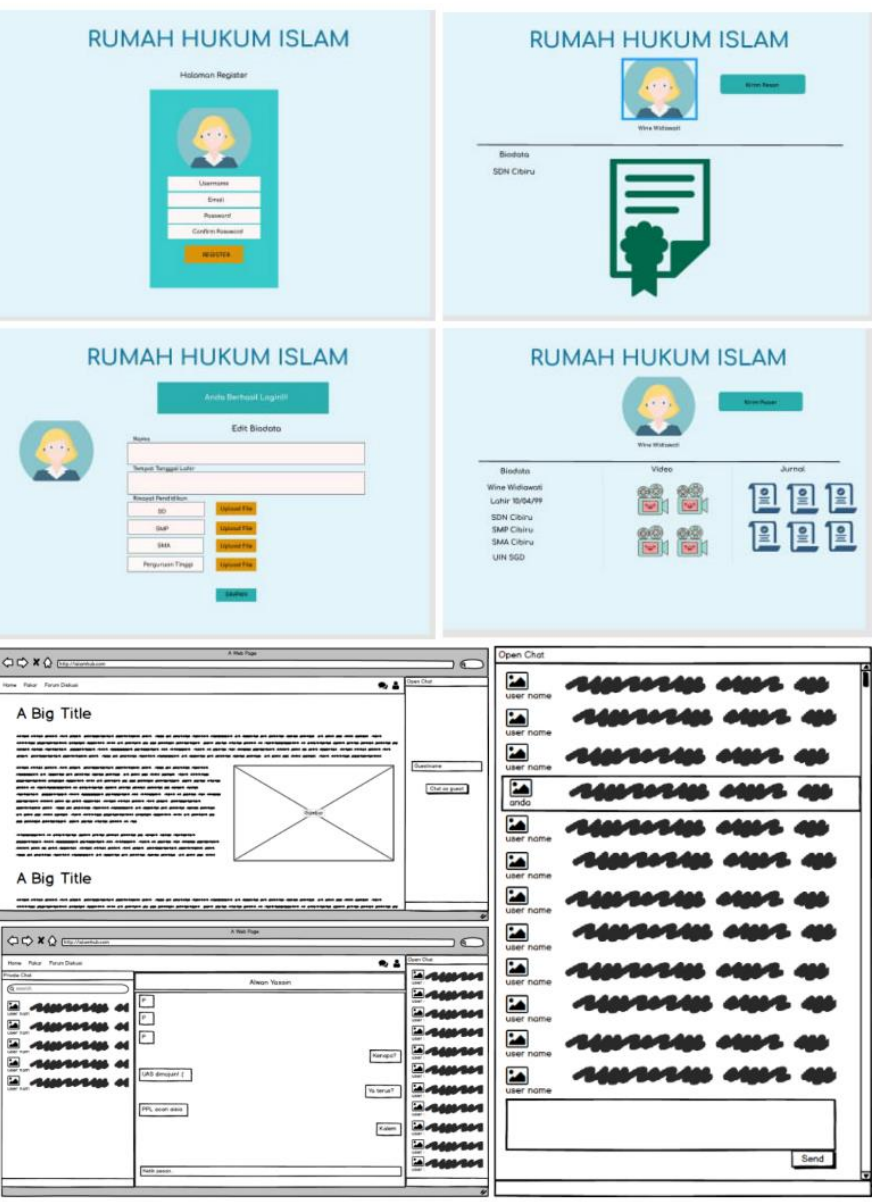

Fig. 8. The example of user interface design of RKHI.
6) Sprint retrospective meeting: Testing software using the Scrum method is known as integrated testing. So, at each integration test, black box testing is also carried out to ensure that each unit and module integrated is running according to its function [42].

7) Product release: Product release is the stage of hosting the system online so that the system can run and be used by users in general. Figure 9 shows an example of RHKI implementation in terms of database implementation and user interface implementation.

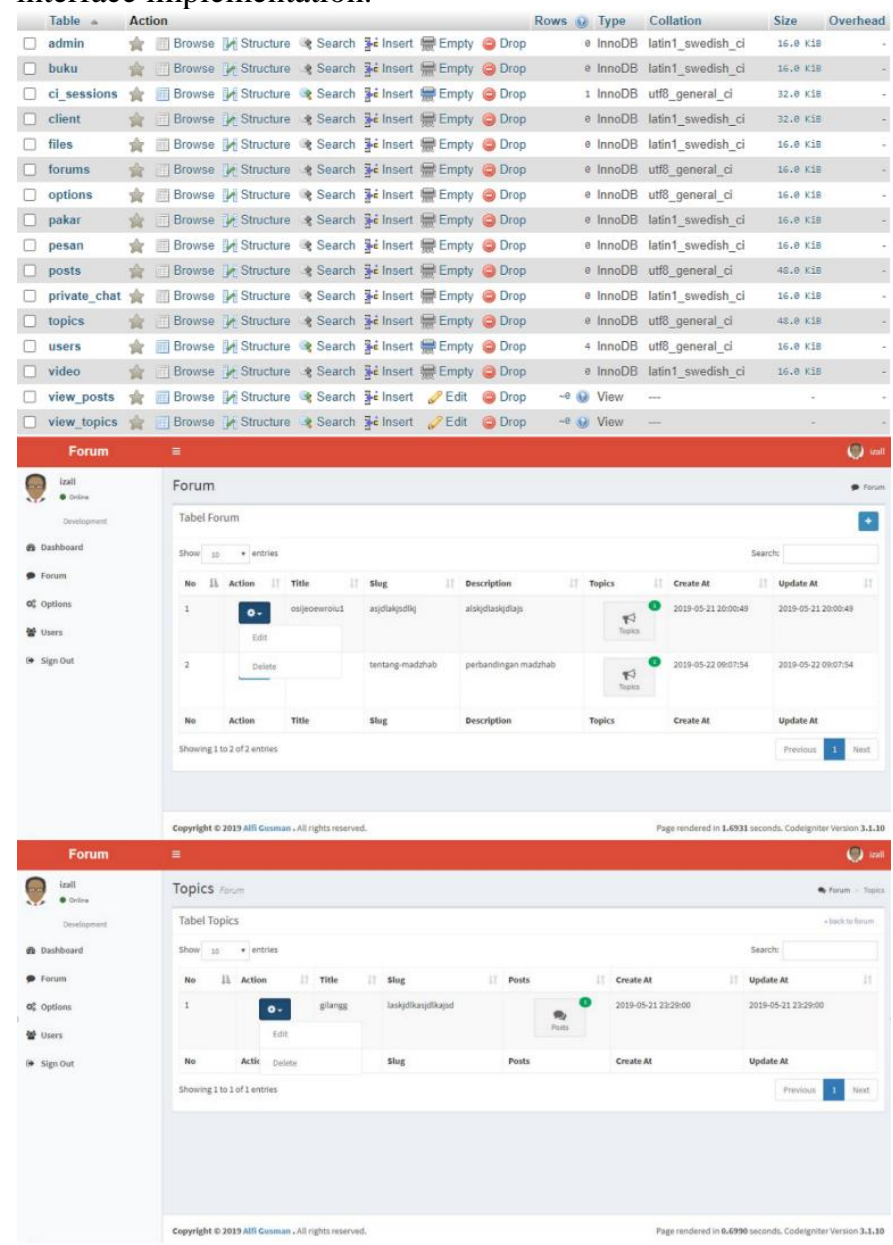

Fig. 9. The example of implementation of RKHI

\section{CONCLUSION}

Information technology can now be used in various fields, including education. Web-based applications, which are part of technological development, are an effective medium for community education. This research produces a web-based educational media that can be accessed by the wider community that provides information and consultations about Islamic law. By using the Scrum methodology as a software development method, the information system which is named "Consultation House of Islamic Law" has been successfully implemented by means of black box testing that ensures all 
functions of the system run well. For future research, this system can be developed with various additional functions according to the needs and technological developments, for example by adding a recommendation system or decisionmaking system to serve client consultation, or recommending expert expertise in accordance with the problems faced by the client.

\section{ACKNOWLEDGMENT}

We would like to say thank you to Postgraduate Program of UIN Sunan Gunung Djati Bandung that support and funding this research publication.

\section{REFERENCES}

[1] Anonymous, "3,9 Miliar Orang di Dunia Telah Terhubung Internet," CNN Indonesia, 2018

[2] Anonymous, "Tren Internet 2019, Statistik \& Fakta di AS dan Seluruh Dunia," vpnMentor, 2018

[3] Y. Pratomo, "APJII: Jumlah Pengguna Internet di Indonesia Tembus 171 Juta Jiwa,” Kompas.com, 2019.

[4] R.K. Nistanto, "Riset: Penetrasi Internet Indonesia Naik Jadi 56 Persen," Kompas.com, 2019. .

[5] Anonymous, "DATA TERBARU, Jumlah Penganut Agama di Dunia," tomoutonews.com, 2018.

[6] Anonymous, "Top 10 Populasi Umat Muslim Terbesar di Dunia," Muslim Pro, 2019.

[7] M. Mardani, "Hukum Islam Dalam Sistem Hukum Nasional," J. Huk. Pembang., vol. 38, no. 2, p. 175, 2017

[8] Rohidin, Pengantar Hukum Islam (Dari Semenanjung Arabia Sampai Indonesia), 1st ed. Yogyakarta: Lintang Rasi Aksara Books, 2016.

[9] Marzuki, "tinjauan umum tentang hukum islam."

[10] Mardani, Hukum Islam; Pengantar Ilmu Hukum Islam di Indonesia. Yogyakarta: Pustaka Pelajar, 2015.

[11] M.K. Al-Qhattan, At-Tasyri' wa al-Fiqh fi al-Islam: Tarikhan wa Manhajan. Maktabah Wahbah, 1976.

[12] F. Djamil, Filsafat Hukum Islam. Jakarta: Logos Wacana Ilmu, 1997.

[13] S. Khosyi'Ah, M. Irfan, D. S. Maylawati, and O. S. Mukhlas, "Analysis of Rules for Islamic Inheritance Law in Indonesia Using Hybrid Rule Based Learning," in IOP Conference Series: Materials Science and Engineering, 2018, doi: 10.1088/1757-899X/288/1/012133.

[14] R. Setiawan, D. Destiani, and C. Slamet, "Perancangan Sistem Pakar untuk Pembagian Waris Menurut Hukum Islam (Fara'id)," J. Algoritm., vol. 09 , no. 01, pp. 1-8, 2012.

[15] S. Susilowati, "Pengembangan Sistem Informasi Manajemen Zakat, Infaq, Shadaqoh, Waqaf dan Hibah Menggunakan Metode Waterfall," Paradig. - J. Komput. dan Inform., 2017.

[16] R.A. Iswara, E. Santoso, and B. Rahayudi, "Sistem Pendukung Keputusan Untuk Penentuan Mustahik (Penerima Zakat) Menggunakan Metode Fuzzy AHP (F-AHP)," J. Pengemb. Teknol. Inf. dan Ilmu Komput. Univ. Brawijaya, 2018
[17] D. Supriadi and L. Fitriani, "Perancangan Sistem Informasi Zakat Berbasis Web," IJCIT(Indonesian J. Comput. Inf. Technol., 2018.

[18] S. Sotar and D. Mardianto, "Sistem Informasi Geografis Daerah Yang Layak Menerima Daging Qurban Di Wilayah Kota Padang,” J. REST (Rekayasa Sist. dan Teknol. Informasi), 2018, doi: 10.29207/resti.v2i1.244

[19] "dakwah.id."

[20] M.N. Ulama, "MNU Online.".

[21] "Konsultasi Syariah.".

[22] C. Nafis, "CholilNafis.com.".

[23] S. Khosyi'Ah, M. Irfan, D.S. Maylawati, and O.S. Mukhlas, "Analysis of Rules for Islamic Inheritance Law in Indonesia Using Hybrid Rule Based Learning," in IOP Conference Series: Materials Science and Engineering, 2018, vol. 288, no. 1.

[24] A. Rozaq, K.F. Lestari, and S. Handayani, "Sistem Informasi Produk Dan Data Calon Jamaah Haji Dan Umroh Pada Pt. Travellindo Lusiyana Banjarmasin Berbasis Web,” J. POSITIF, 2015, doi: 10.1117/12.532107.

[25] D.R. Firmanda, R.R. Isnanto, and I.P. Windasari, "Aplikasi Pembelajaran Manasik Haji dan Umroh Berbasis Android," J. Teknol. dan Sist. Komput., 2016.

[26] L. Sudarmana and W.S.A.K. Putra, "Membangun Sistem Pendukung Keputusan Biro Perjalanan Haji,” Simetris, 2017.

[27] R. S. Pressman, Software Engineering: A Practitioner's Approach, 7th ed. New York: McGraw-Hill, 2011.

[28] I. Sommerville, Software Engineering. 2010.

[29] A. Moran, "Agile software development," in SpringerBriefs in Computer Science, 2014.

[30] V. Upadrista, "Agile Methodology," in The Art of Consultative Selling in IT, 2015 .

[31] M. McCormick, "Waterfall and Agile Methodology," in MPCS Inc, 2012.

[32] S. Sachdeva, "Scrum Methodology," Int. J. Eng. Comput. Sci., 2016

[33] K. Schwaber and J. Sutherland, "The Scrum Guide," Scrum.Org and ScrumInc, 2013

[34] M. Rasyidi, Keutamaan Hukum Islam. Jakarta: Bulan Bintang, 1971

[35] A.R. Rosyadi, Formalisasi Syariat Islam dalam Persfektif Tata Hukum Indonesia. Bogor: Ghalia Indonesia, 2006

[36] A. Kadir, Pengenalan Sistem Informasi Edisi Revisi. 2014.

[37] J. Hutahean, KONSEP SISTEM INFORMASI. 2014.

[38] Jerry FithGerald, "SISTEM INFORMASI," Konsep Sist. Inf., 2011.

[39] R.E. Indrajit, Manajemen sistem informasi dan teknologi informasi. Jakarta: PT Elek Media Komputindo, 2001.

[40] D. Sa'adillah Maylawati, M. Ali Ramdhani, and A. Syakur Amin, "Tracing the Linkage of Several Unified Modelling Language Diagrams in Software Modelling Based on Best Practices," Int. J. Eng. Technol., 2018.

[41] Booch, "The Unified Modeling Language User Guide," Addison-Wesley Object Technol. Ser., p. 496, 2005.

[42] D. W. Utomo, D. Kurniawan, and Y. P. Astuti, "Teknik Pengujian Perangkat Lunak Dalam Evaluasi Sistem Layanan Mandiri Pemantauan Haji Pada Kementerian Agama Provinsi Jawa Tengah,” Simetris J. Tek. Mesin, Elektro dan Ilmu Komput., 2018. 